\title{
Niyoga [Levirate]: Conflict Resolution to Bruised Masculinity in Early India
}

\author{
Smita Sahgal
}

\begin{abstract}
There is a perception that conflict often emerges in context of tangible violence. What gets missed out is that certain types of social norms and expectations can also be instrumental in germinating mental conflict which may not get explicitly articulated. Sometimes such conflict situations may require resolutions or cultural mediation. One such situation in Early India was the absence of son in household who apparently held the key to happiness of both this world and the other. Sons were the index to an individual's masculinity, testifying his virility and fertility, apart from being the perpetuators of lineage and property. What would happen if a man failed to reproduce because of impotency or early death? The ensuing conflict could dent his masculinity or the memory of it. Niyoga was a mechanism of healing a man's masculinity. It intended to resolve conflict both within private and public domains. The purpose of the paper is to locate this practice within the discourse of masculinity in Early India.
\end{abstract}

Index Terms-Bruised, impotency, lineage, levirate, masculinity.

\section{INTRODUCTION}

Conflict can arise in public as well as private domains. Violence may usually be associated with blatant use of force but there can be occasions when certain social practices or norms can appear psychologically violent and create situations of conflict that may require resolutions or cultural mediation. One such situation in Early India was the absence of son in household who apparently held the key to happiness of both this world and the other. Early Indian literature, especially the Sanskrit texts, prescribes procreation as the foremost religious and social duty of men and women. Begetting was not envisaged as a simple act of biological reproduction nor sex reckoned as an autonomous realm. Right from the time of the Rik samhita [X.85.27], the coming together of a man and woman in a heterogeneous sexual union was envisioned to perpetuate lineages [1]. The purpose of marriage was stated to be the creation of progeny. In the Surya marriage hymn of the tenth mandala, Prajapati is invoked to, "bring forth children to us" [X.85.43]. Manu [IX.96] informs us that women were created to bear children, and men to carry on the line; that is why the revealed canon prescribes a joint duty [for man] together with his wife. We are further informed that '.. the wife was the field and the husband the giver of seed' [2].

For both men and women the primary duty was to

Manuscript received September 4, 2014; revised December 24, 2014 This work was supported in part by Indian Council of Historical Research

Smita Sahgal is with the Department of History, Lady Shri Ram College, University of Delhi, Delhi-110007, India (e-mail: smitasahgal16@yahoo.com). reproduce and failure to do so could result in social ostracization. Reproduction and becoming a mother of sons was projected as the ultimate goal of a woman's sexual-social existence and the desire to procreate was perhaps a legitimate desire. Similarly a man's primary duty was also to procreate: have sons so that the lineage could be perpetuated, property inherited and manes satiated.

\section{A. Defining Niyoga and Stating Its Relevance}

But what would happen if he failed to reproduce because of impotency or early death? This could dent his masculinity or the memory of it. The norm setters of the day found an alternative mechanism in niyoga or levirate. Niyoga or levirate has been defined by P. V. Kane as the 'appointment of a wife or a widow to procreate a son from the intercourse of with an appointed male' [3]. The method or strategy had a legal and social sanction with the details of the procedure often being delineated in the texts or followed as a method of tradition. It was an attempt to circumvent human infertility through assisted reproductive technique. By and large it was the wife of an impotent or dead man who was asked to cohabit with another man to produce an heir for the husband. However, in rare circumstances the equation could be reversed wherein the husband of a barren woman could also enter into an alliance with the wife of another man to produce an heir.

Therefore niyoga may be taken as a special provision in the sexual ethics of early India; not just a response to the appati [emergency] occasioned by childlessness and therefore belonged to the category of practices excused by apaddharma, or laws of exigency but also a mechanism of healing a man's masculinity that would get bruised with the acknowledgement of his impotency. So even if the practice was not considered very honorable during the normal course of things, it could be resorted to with impunity in the case of absolute necessity. The participants in the niyoga arrangement were the kshetra [field] or the wife; Kshetrin [also called kshetrika] or the husband who owned the field, the kshetra. The person who was appointed to produce the offspring or offered his seed was called the biijn or niyogin and the product/son is called kshetraja.

The purpose of the paper is to locate this practice within the discourse of masculinity. The idea is to delve into the issue of masculinity in early India and situate niyoga therein. For this we may have to deal with the issue of masculinity. We also have to reflect on the social formations of the groups practicing it. But before we do that it is important to locate our sources and locale of study. We need to assess the complex conflict resolutions that came through the practice.

For the reconstruction of niyoga in Early India and Early 
Medieval period, we have to access Vedic literature, Epics, Puranas, Dharmashastras, Smritis and medieval commentaries on them. Most of these sources are brahmanical and give us a view from an elitist vantage. The period is largely between what is construed from early Vedic sources i.e. around $1500 \mathrm{BCE}$ to around $750 \mathrm{CE}$. We will stretch the time frame till 1200CE to look into the commentaries of the Dharmashastras and the Puranas. The locale is largely north India though we may get some references to the south as well.

\section{B. Social Formations of Niyoga}

The social preoccupation with procreation and therefore with niyoga appears to be rooted in concrete economic logic. Human resource was precious in the days of uncertain material reserves. Each member of the band /household was a unit of production. More food could be secured with more hands and available labour. One fundamental anxiety was to ensure population growth. To paraphrase M. Foucault, a very basic concern of sexuality had been to reproduce labour capacity, to perpetuate the forms of social relations, to constitute a sexuality that would be economically useful and politically conservative [4]. No wonder food and progeny occupied an equal space in their prayers and rituals. In many passages of the early texts clear importance was attached to symbolic copulation as a means of generating offspring and cattle [5]. Sometimes the act of sowing seed in the field was likewise thought in terms of sowing seed in the womb as can be inferred from a verse in Taittiriyasamhita [IV .2.5.5] [6].

Niyoga was institutionalized in societies of pastoralists and early farmers. The term received its formalization much later but practices akin to it could be cited right from the days of the social set up reflected in the Riksamhita. Additionally the societies were likely to be patriarchal, patrilocal and patrilineal where inheritance would be through husband's line. Some of the groups practicing niyoga also followed the tradition of acquiring the wife through the payment of a bride price [shulka], something that was recognized by Manu as well. The wife in such a social set up would be integrated within the husband's family to the extent that she would not be welcomed in her natal group on her husband's death or in case of a separation. There was hardly any scope of her inheriting property at that end. In a sense then niyoga acknowledged the investment made by husband's family in acquiring the bride and also their right on her fertility and labour in case the husband died without leaving an heir or turned out to be impotent. Cultures that followed the practice tended to be exogamous; marriage within the clan or group was discouraged or even forbidden as this precluded the possibility of man's sister-in-law turning out to be a blood relative.

\section{TOWARDS A DEFINITION OF MASCULINITY}

The usage of the term depends on a series of precise or implied premise. More often than not, anatomy becomes the bedrock of masculinity. It is the possession of 'penis'/phallus upon which the masculinity is supposedly predicated. The sexual and procreative functions have been cited as the most enduring characteristics of masculinity. The shorter Oxford Dictionary tells us that a 'male' is 'of or belongs to the sex that begets offspring, or performs the fecundating function' and 'masculine' has, 'the appropriate excellence of the male sex; virile, vigorous and powerful'. Masculinity almost appears as an essence or commodity, which can be measured, possessed or lost. The possibility of something like 'failed masculinity' or 'emasculation' reinforces the idea that masculinity is supposed to be a characteristic of men. Even as there is no rigid classification of masculinity, virile sexuality, fertility, acquisition and display of power in the public and household domains as well as the demonstration of temper and physical strength especially in violent acts/activities such as wars, along with the style of confrontation [ as in a boxing rink] are some acknowledged traits associated with masculinity. Conversely impotency, homosexuality, physical weakness, public exhibition of emotions and giving in to defeat would be reflective of 'failed masculinity' or 'feminized men'. Femininity is by and large distinguished from masculinity on the basis of subordination of women to men. It may acquire different forms. One form is defined around compliance with this subordination and is oriented to accommodating the interests and desires of men, which is often called 'emphasized femininity'. Others are defined by strategies of resistance or forms of non-compliance [7]. Still others are delineated by complex strategic combinations of compliance, resistance and co-operation, something that we have referred to above. When women are assertive, physically strong or enter public arena they are often called masculine. Moreover masculinity and femininity are not exclusive to men and women; these are constructs that permeate the worlds of homosexuals as well.

There is no discourse on masculinity per se in Early Indian texts; however the idea of masculinity does run through various texts. The first requirement is to work out a tentative definition based on different terms that we come across in the literature. Interestingly the term 'masculinity' does not occur in Monier-Williams, 'A English- Sanskrit Dictionary', though we do come across terms like 'man' [purusa, vira] 'manly' [paurusah, Viryogyah, virah, mahaviryah, narah] [8]. 'manliness' [paurusama, viryam, parakrama, sahasam, surata, manusyatvam] masculine' [Paurusah, Parusheyah, purusajatiyah] 'masculinely'[purusvat, naravat, paurusena] [8] and 'masculineness' [purusvtvam, paurusam, paurusta, purusasilata, purusasvabhavah, purusaprakrti]. Additionally manhood is understood as pumstva, purustva, 'masculine gender' is referred to as pulingam and puman, 'manly act' is puruskara, 'manly duty' is naradharma , 'someone resembling a man or having the qualities of man' is referred to as aklivah and 'a masculine woman' is called rsabhi There are also words such as kimpurusa [evil man or a monkey like man], Khliba [9], pandaka [passive homosexual] and na-pumsaka [non-man] that may be construed in opposition to what has been understood as 'manliness' in a larger question on masculinity.

From the analysis of the associated terms and the study of the contexts of their occurrences, it appears that even when there was no pointed debate on the concept, it preoccupied the thinkers and mythmakers of the day in a very pervasive 
way. We can only attempt to build a tentative framework around its varied dimensions. As it were the case in many other cultures, here too, one of the most defining attributes of what can be conjured up as masculinity was voracious sexual potency. This allegedly decided a man's procreative potential. The identity of a 'complete man' was reckoned in terms of his ability to have male offspring who were sought to perpetuate his lineage, ensure property transmission within family and open the floodgates of heaven for him. Within Brahmanical framework rituals were prescribed to strengthen father-son bond that went apparently beyond the worldly context.

This kind of masculinity demanded a public acknowledgement or denial of physical faultlessness. The smritikaras [norm-setters] demanded that the bridegroom be examined before marriage. So many measures were suggested to test the potency of his semen, the ultimate life force. Numerous categories of impotent men were specified and suggestions given to overcome curable impotency. An impotent man was denied the right to inherit property or participate in rituals for the ancestor. The king was advised to ignore him as he was a weakling. Being a napumsaka amounted to public humiliation. Andrea Custodi is correct in stating that men had to establish their manhood the way women did not to have to prove their femininity. In fact women were given the right to remarry or abandon their husband if he turned out to be khliba, a 'not a man'. Even if the measures suggested in the Dharmashastras [texts on social norms] to prove a man's masculinity was not followed in totality, the theoretical regulations suggested did create an image of an ideal man. Young boys who would have been pressurized to internalize the construct would, in course of time, refuse to accommodate any image less perfect. No wonder they castigated themselves or others for "not being a man' on account of physical weakness or refusal to take up challenges. The kind of masculinity we are referring to could be discussed within the ambit of 'hegemonic masculinity'; very discriminatory and power oriented. The image of being less than a 'complete man' would have created mental havoc for the individual, a kind of conflict that required mediation of some sort. Niyoga or levirate was an attempt to resolve this conflict.

\section{NIYOGA WITHIN THE EMERGENT FRAMEWORK OF MASCULINITY/IES}

Where do we locate the instrument of niyoga within the framework of masculinity? In such a discussion we need to observe the positions of various male actors such as those of the kshetrin or begetter [the legal father], who gets the progeny, the genitor or the biological father, and the product or the male progeny, the kshetraja to gauge multivalent perspectives on the impact of the practice on their construct of masculinities.

Niyoga was an apparent strategy to overcome an apparently emasculated existence. As mentioned above, resorting to this option was also tantamount to an open acknowledgement of one's impotency or khlibavada. However, this was apparently the lesser of the evils; accepting one's impotency was a lesser sin than not attempting to overcome its social implications. Those who were impotents or belonged to the third gender [napumsakas and khlibas] stayed on the margins of the brahmanical world view. The implications of being impotent were varied and harsh, which one would experience both in public and private spaces. Publically it implied a loss of face before others, becoming an object of ridicule but more important it amounted to debarment from inheritance, exclusion from performance of rituals especially the ancestral rites and at spiritual level it supposedly spelt out the closing of the door of heaven on one's death.

Niyoga appeared to be a fairly complex solution and the man who resorted to niyoga had to make adjustments at numerous levels. Apart from psychological retuning it also implied social reorientation. At a personal level it would entail renegotiation of relationship with one's spouse. The absence of virile/fertile 'manliness' could result in losing a wife as the Dharmashastras did allow a woman to re marry on this count. The image of a husband that she must have ideally internalized over years; of a strong, virile and fertile man who would also be her protector, would get dented on revelation of his being impotent. To this would be added her fear of remaining childless and without old age security. At the same time allowing the wife to have sexual relations outside his marriage would also bruised his manhood. However, securing an heir would be equally difficult without her entering into such an alliance. For any one experiencing 'inadequate' manliness the fear of complete social and domestic marginalization would have been very real. Despite the situation getting confounded niyoga emerged as the only rescue device and the husband may actually encourage the wife to enter into a relationship with a designated man or even support the choice she made.

The Dharmashastras sanctioned property inheritance through it. Manu [IX.203] mentions that an impotent man who has acquired wives and gets son of the relationship would be entitled to a share in the property. The kshetrin or husband of the kshetra reserved a position in the heaven as the son redeems the father of his sins and invests immortality on him. The kinship and family framework would be sustained as kin would accept him as the father of the child, the wife would stay with the spouse and the child/son would acknowledge him as the father. He too gets to participate in the upbringing of his son. So denting and healing of one's manhood was simultaneously achieved through this instrument. No wonder at the mythic level we have so many stories of husbands instructing their wives to cohabit with a bijin or giving their tacit support when she sought a partner. Kings or the royal kinsmen were extremely worried about the threat to their lineage and, hence, most vocal to its adoption. The 'manly' king had to particularly ensure a successor.

There is little doubt that niyoga was a highly regulated practice. The preferred surrogates included devara, the younger brother-in-law, Brahmins and the gods. In the Riksamhita Asvins assisted Vimada's wife. The twins also gave Vadhrimati a son, Saivya. Varuna and Indra helped Purukutsa's wife in getting a progeny when the latter was held in captivity. Mugdalini was also possibly helped by 
someone with the vigour of bull in procurement of children [X.102]. In the Mahabharata, Sharanandayani was instructed by her husband to select a Brahmin and get sons from him. King Kalmasadpada made his wife cohabit with his teacher Vasistha from whom numerous sons were born. We are also familiar with the other Mahabharata stories such as those of Veda Vyas [I.113.2] begetting progeny on his brother's widows on the request of his mother [10] and of Pandu requesting Kunti to help him secure a share in the kingdom and a place in heaven by resorting to the practice. Kunti protested giving Bhadra Kakshivati's example but finally gave in. Even as the practice became rare subsequently the Puranas give us its continuity in the stories of kings Bali, Dirghtamas and queen Sudesna [11] and also the yavana king who requested known brahman sage Gargaya to become progenitor to his children [12]. Gargaya had been ridiculed by Yadav rulers as an impotent man and deliberately sired sons on Yavana ruler to prove his manhood.

How do we classify the masculinity of men who resort to niyoga? If we go by Connell's categorization, the masculinity of the begetter [and times of the genitor/bijin too] can be placed within the framework of 'complicit masculinity'. They are men who may subscribe to the hegemonic project but do not embody hegemonic masculinity. Masculinities constructed in ways that realize the patriarchal dividend without the tension or risk of being the front line troops of patriarchy, are complicit in this sense'[7]. Connell calls them a slacker version of hegemonic masculinity. Somewhere they have internalized the ideal of hegemonic masculinity but real life compromise in marriage, fatherhood and community life keep them away from 'naked domination and uncontested display of authority.' [7]. Resorting to niyoga may then imply readjustments at various levels but it also implied a tacit acceptance patriarchal ideals and values. Rarely do we come across voices questioning the logic and need of this strategy of heirship.

Complicit masculinity is also reflected in the actions of those commissioned to procreate. So many times they take up the responsibility only to reiterate the hegemonic/upper caste ideal of perpetuating a lineage. The levir or niyogin may actually encounter complexities in subscribing to such an action and yet do it in the name of larger social [patriarchal] good. For a devara [younger brother-in-law] the situation would be really complex. The niyoga relation may place emotional stress on the devara, as it required him to cohabit with a woman he had previously regarded as forbidden. He might oblige under social duress but may remain extremely uncomfortable with the idea of entering into a relationship with a reluctant woman. This kind of situations could be encountered by other brahman levirs as well. The fear of rejection was a real one. In the Mahabharata, Veda Vyasa warned his mother that her daughters-in-law may not tolerate his smelly being. Dirghatamas was equally appalled at Sudesna's resistance and cursed her children. In fact, Dirghatamas seemed to have convoluted views on the issue of woman's protest in an unwilling relationship [11]. Within the niyoga format, it was not just the issue of being rejected by unwilling partners but also the problem of wasting way their semen or life force on others when their biological children would never be known by their name. In the Bible [Genisis.38], Onan the brother-in-law of Tamar, purposely wasted his semen as he knew that his children would only be known by the name of his dead brother.

Complicity in masculinity was not without its share of complexities. There could also be the issue of developing a genuine affection for the sexual partners. The normative texts forbid the process to be anything but short-termed, swift, clinical and detached. This may not always be the case, especially when the couple waits for the male child/children to be born and there only girls are reproduced. Affection for a woman other than one's own wife would not fit within parameters of ideal masculinity. Additionally if the niyogin was the brother-in-law, there would have been the psychological problem of adjusting to the shifts in the relationship with his sister-in-law on the one hand and his wife on the other. The virility of the 'man' could also bring in its share of problems. His masculinity could be easily dented in the face of opposition from the niyoga partner and the very crucial decision to give up his paternity rights on his biological child. At the same time we must not lose sight of isolated cases as those of brahman Gargya which appear in the Puranas and who was most willing to act as a bijin and procreate in order to prove his manliness and take revenge on those who ridiculed him as impotent. For him the concern was not the continuation of a lineage as would be the case with Yavana ruler but proving his virility and fertility and seeking revenge [12]. This was a case where the interest of both men colluded and none had to compromise.

The progeny of such unions may have also undergone complexities in life. The issue of double paternity and the epithet of dvapita, [one with two fathers] could make a kshetraja an object of scorn among his peers, especially at a time when the commentators of the smritis had begun proscribing the practice of niyoga from the early medieval period. In the Dutavakya of Bhasa [V.21], Duryodhana refused to recognize Pandu as heirs because they were born of niyoga. It was almost an abuse hurled at them. The episode is interesting as even when Duryodhana ridiculed his cousins, he conveniently forgot that he himself was not completely free of a niyoga connection. After all, his father was also born of one [10].

It is quite possible that, within one's self estimate, the issue of double paternity or a non biological paternity could bring in confusion. Pandu is the best example of this kind of confounded masculinity. He was a product of a niyoga union and also begot children form such an arrangement. Pandu could never forgive his legal Kshatriya father, Vicitravirya, for leading an unfettered lustful life that, he assumed, became a curse to his sexual potency. Yet he found himself addicted to acknowledge Kshatriya passions of hunting and gambling. He finally chose an austere existence of his brahman biological father, Veda Vyas, as a mode of penance. At the same time, the legitimate Kshatriya requirement of seeking sons to perpetuate his lineage and claim his share in the kingdom forced him to beget children through niyoga. The instrument of niyoga caught him an intricate web; made him lament his fate and paternity but also provided him with an ostensible alternative for social reintegration and spiritual 
ascendancy. Certainly niyoga provided a complex conflict resolution to him that both confounded him as well as provided him with resolution to his problem.

The myth of king Kalmashapada whose wife mated with his teacher, Vashistha reveals that niyoga as practice could bruise a man's ego substantially even as it may eventually come to his rescue. There are significant strains of tension between the kshetrin and niyogin in this case and some may have arisen out of his suspicion of the wife being/ becoming close to the bijin/ niyogin.

However, we also have examples of some epic characters who proudly asserted their niyoga credentials. In the Vanaparva section of the Mahabharata, Hanuman while introducing himself to Bhima states, 'I was begotten on Kesarin's field [kshetra] by the wind [Vayu], who is life breath of the world' [III.147.20-25]. For the kshetraja Hanuman, association with his biological father was as much a matter of pride as his relationship with the father who begot him. The dvapita syndrome does not bother him at all.

The kshetraja critique of the practice may come in oblique ways. Arjuna, in the Mahabharata, who himself was a product of a niyoga union, questioned the one between Kalmashapada's wife and the king's teacher, Vasistha. He called it unlawful and could not believe that as great a king as Kalmashapada could let his masculinity be breeched by allowing a union between his wife and his teacher. Arjuna's comment appears to be ironic. What could trigger his reaction when he knew that he himself was a product of such a union? [I.182.1 ff]. This could probably be because Arjuna thought that he was above board on account of his semi-divine origin, or else the point of critique was the relationship between a guru's wife and his student. Such niyoga practices were normally forbidden. There were exceptions though as we have already seen in the case of Uddalaka who had his son Shvetaketu through this practice. Shvetaketu, the kshetraja in this case, is supposedly the author of fresh patriarchal constraints to a woman's sexuality. On a closer look he appears to be a victim of psychological complexities emerging out of his mother's polyandrous existence that could have brought in the issue of his legitimacy as well. His dictate to tie down women to their husbands alone, once again appear to be emerging out of a situation he found difficult to reconcile; multiple sexual relations of his mother even as his father was possibly an impotent. Historically he represents a transitional phase in the reformulation of patriarchal norms possibly from a freer tribal set up to a more closed caste based society. This would have coincided with gradual objectification of women especially in the context of the household. The complicit masculinity of a kshetraja was certainly moving towards the disposition of the hegemonic as Shvetaketu donned on the cap of an arbiter of social norms.

The legal problems would abound around the issue of inheritance. A kshetraja certainly stood to gain the name and property of his legal father and at times of his biological father too but always stood next to an aurasa, the biological son, in the list of acknowledged sons in law books. If a biological son were born after him, the latter stood to gain, both in terms of legal inheritance as well father's affection. This could bring about tension between the two brothers on a variety of issues.

\section{CONCLUSION}

As the notion of ideal masculinity changed with time, so did its relation with the institution of niyoga. From the male perspective niyoga may appear to be a curious devise that sought to simultaneously puncture and sustain one's masculine sensibility. Social healing to bruised masculinity could come through the practice of commissioned procreation, though at a price. The husband would have to share his wife with another man, the niyogin/bijin. The niyogin on the other hand, would have to tolerate a reluctant partner or camouflage his affection for her if they struck an emotional cord. Moreover, he would also have to renegotiate another relationship with his own spouse. The progeny would have come to term with diverse baggage of emotions; ridicule, love, envy, comfort and anger.

Even when there was a gradual proscription of the practice, it continued on margins for long time. Dayanand Saraswati [nineteenth century] advocated its revival and his discourse can be situated in the context of a perceived 'emasculated' nation and the need to recreate a strong Aryan race to rescue the society. It continues in a modified way to this day. The modern system of artificial insemination after considered gene selection comes quite close to it but for a major difference. The process is a clinical process and it omits the performance of a sexual act. The social implication of this can be immense for an individual's masculinity as the public declaration of impotency is skipped over and the compromise to a man's dignity on sharing his wife/ property could be avoided. There is little doubt that even as centuries have gone by the notion of masculinity continues to hinge on sexual might and ability to reproduce as primary attributes. The complexities emanating out of the practice might have been ultimately responsible for its legal discontinuity. In early India, however, niyoga did provide a solution to wounded masculinity.

\section{REFERENCES}

[1] R. T. H. Griffith, Rik Samhita (the Hymns of Rigved), Motilal Banarsidass, Delhi, Reprint 1991.

[2] W. Doniger and B. Smith, The Laws of Manu, Tr. Penguin Classics, 1991.

[3] P. V. Kane, History of Dharmasastras, Bhandarker Oriental Research Institute, Poona, 1974, p. 599.

[4] M. Foucault, The History of Sexuality: An Introduction, Penguin Books, London, 1990, p. 37.

[5] A. B. Kieth, "Aitareya Brahmana," Harvard Oriental Series, vol. XXV, Cambridge Mass, 1920.

[6] A. B. Kieth, "Taittiriyasamhita," Harvard Oriental Series, vol. XVIII, Cambridge Mass, 1914

[7] R. Connell, Gender and Power, Society, the Person and Sexual Politics, Stanford University Press, Stanford, 1987, p. 184.

[8] M. M. Williams, A Dictionary, Sanskrit to English, Motilal Banarsidass, Delhi, reprint, 1999.

[9] W. Doniger and B. Smith, Laws of Manu, ed. Penguin India, Delhi, 1999, p. 58.

[10] V. S. Sukhtankar, Mahabharata, ed. Critical edition published by Bhandarkar Oriental Research Institute, vol. 19, ch. 1, Poona, 1933.

[11] G. V. Tagare, "Brahmanda Purana," in Ancient Indian Tradition and Mythology, J. L. Shastri ed., Delhi, King Bali requested sage Dirghtamas to sire sons on his wife Sudeshna so that his lineage could 
be perpetuated, Queen Sudeshna did not tolerate the old and ugly sage, vol. 22-26, 1984.

[12] H. H. Wilson, Vishnu Purana, vol. 5, London, 1864-1870, Indian edition, vol. 2, Delhi, 1980, reprint 1989, chapter XXIII

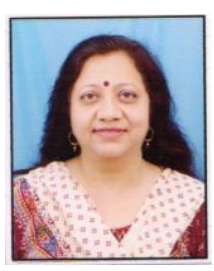

Smita Sahgal is from Delhi, India. She did MPhil on 'Spread of Jinism in North India between C.200BC and 300CE' with special reference to Mathura form University of Delhi where she also pursued her PhD programme on the topic, Bull Cults in North India: A socio-religious study up to 500CE' and completed it in 2004. Currently she is working as an associate professor in the Department of History, Lady Shri Ram College, University of Delhi. Her post doctoral research project was sponsored by Indian Council of Historical Research and was on 'Niyoga: Commissioned procreation and sexual regulation in Early India [A Socio-Historical Study in North India between $1500 \mathrm{BCE}$ and $700 \mathrm{CE}$ ]' The monograph is to be published shortly

Dr. Sahgal is a member of Indian History Congress and Indian Society of Buddhist Studies. She was awarded junior research fellowship by the UGC, 1987, Cleared National Education Test, 1987. She also received Indian History Congress Prize for the Best Paper on Ancient India, Shantiniketan, 2006. Dr. Sahgal was also recognized as the best promoter of Indo-Romanian Relations, in the field of Culture and Education, New Delhi, 2008. She has over twenty publications to her credit and has made nearly thirty presentations in various seminars and conferences. 